\title{
THE REPRESENTATION OF BASQUE IMMIGRATION IN AMERICAN CINEMA: Wild is the Wind (1959) or the Quest for Elucidating What a Basque Is
}

La representación de la inmigración vasca en el cine de Estados Unidos: Wild is the Wind (1959) o la búsqueda por determinar qué Oscar es un vasco

\begin{abstract}
In previous studies I have presented a general overview of the way American Cinema depicted Basque people, and especially Basque immigrants in the American West, and its evolution since the times of silent cinema to our days. In this article I will analyse one of the very first films in which a Basque character is presented, not in a secondary role, but as a protagonist. Wild is the Wind (George Cukor, 1959) represents also one of the first approaches to the representation of Basque identity by a Hollywood A-movie (this is, a film with a high budget, produced by major company, with the participation of wellknown actors and actresses under the control of a renowned director) Firstly, I will summarize the main elements that characterized and conditioned the image of Basque immigrants, and Basque people as a whole, up to the decade of 1990 in the cinema of Hollywood. Secondly, I will describe the process of ellaboration of the film since its first steps, highlighting when, why and by whom was decided to introduce a Basque character in the plot. Finally, I will analyze how this Basque character is depicted in the film, both by the means of external (race, language, clothes...) and internal features (mainly, the dialogues), putting them in the context of previous and contemporary films and tv movies in which Basque characters also appeared.
\end{abstract}

Keywords: Immigration, Basques, Cinema.

\begin{abstract}
En estudios previos he presentado una visión general del modo en el que el cine de los Estados Unidos representó a los vascos, especialmente a aquellos que inmigraron al oeste americano, así como su evolución desde los tiempos del cine mudo hasta nuestros días. En este artículo analizaré una de las primeras películas en las que se introdujo un personaje de origen vasco, no como secundario, sino como protagonista. Wild is the Wind (George Cukor, 1959) representa también uno de los primeros intentos de representar la identidad vasca en una película hollywoodiense de serie A (es decir, con un elevado presupuesto, producida por una compañía grande, con la participación de actores y actrices reconocidos, y bajo el control de directores de prestigio). En primer lugar, resumiré los elementos principales que han caracterizado y condicionado la imagen de los inmigrantes vascos en el cine de Hollywood. En segundo lugar, describiré el proceso de elaboración de este film desde sus primeros pasos, resaltando cuándo, cómo y quién decidió introducir un personaje vasco. Finalmente, analizaré el modo en el que este personaje vasco es representado en la película, tanto a través de sus elementos externos (raza, lenguaje, vestimenta...) como internos (principalmente, el diálogo), poniéndolos en el contexto de otras películas y series de televisión contemporáneas en las que también aparecían personajes vascos.
\end{abstract}

Palabras clave: Inmigración, Vascos, Cine. 


\title{
Basque immigration
}

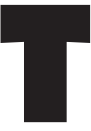

he Basque Country has historically been, during the 19th and 20th centuries, one of the European regions with the highest rate of external, overseas migration, mainly to the Americas, specialy if we compare it in the context of the migratory practices within both states which the Basque lands belong to, France and Spain (DOUGLASS, 2013, p. 3). Even though the political framework the Basque Country is inserted in does not give it some of the basic elements for securing a clear external visibility (Neither is the Basque Country an independent country nor has it a similar degree of cultural recognition and political autonomy in all the territories it consists of), its cultural and linguistic peculiarities, along with a widely accepted, strong sense of identity have led the Basque people to be able to gain some kind of specific recognition as a distinct group to a certain extent in the societies Basque migration mostly preferred to target as the main destination. In countries like Argentina, Uruguay, Cuba, Chile or even the United States (in those parts of the country which were targeted by Basque immigration), there have historically emerged some social constructions on the image and stereotype of the "Basque", either as an immigrant or, more recently, as a hypenated American of Basque descent (TOTORICAGUENA, 2005, p. 4; 209).

Basque modern immigration into the United States started by the middle of the 19th century, and its inception can be directly linked to the Californian Gold Rush of 1849. As it happened to most pioneers that arrived in search of fortune, not much gold was found by those early Basques that settled in the area. Instead, new, unexpected horizons were unveiled:

\begin{abstract}
Certain key individuals in their rank [...] recognized the opportunity afforded by the vast pastures of southern and central California. they became itinerant or nomadic sheepmen, moving about the public lands with their herds - developing a pattern of sheep transhumance whereby they alternated between summer pasturage in the high mountains and the winter range in the low deserts. A they exoanded their operations they attracted to their sides kinsmend and fellow villagers from the Old Country (DOUGLASS, 2013, p. 3).
\end{abstract}

Therefore between 1850 and 1970 it is calculated that about 50,000 Basques immigrated from both the French- and Spanish-Basque regions to the United States (DOUGLASS; BILBAO, 1975, p. 179), most of them to the Western states around the Rocky Mountains throughout the interior Great Basin region, especially California, Nevada, Idaho, and also some parts of Oregon, Utah and Wyoming (DOUGLASS, 1996, p. 186). In all this region sheepherding became almost a synonym for being Basque, since this economic niche became virtually monopolised by Basques in the new pasture areas opened to grazing during the conquest of the American West. As Douglass graphically states (2006, p. 26), "in the twentieth century American West to say 'Basque' is to mean 'sheepherder'" (BIETER; BIETER, 2003). Among other reasons, the long-standing attractiveness of this livelihood for new generations of incoming Basques that replaced the previous ones laid on the ex- 
ceptionally harsh conditions shepherds had to endure: years of a monotonous, lonely life looking after large flocks of sheep in the wilderness. That is why by the mid-1970s, by the hands of the dramatic social, economic and political changes that were underway in the Basque Country, the era of Basque shepherding came to an end: industrialization and the improvement of living conditions and domestic employment opportunities virtually eliminated the immigrant demographic base (BIETER; BIETER, 2003, p. 4-5). Basques started to be replaced by other immigrants, especially Latin Americans, and the traditional image of the Basque shepherd quickly became just an old memory of the West (DOUGLASS, 1980, p. 31).

Altough few in number, and even though there were neither "rural communities or ranching districts dominated by the Basques comparable to the Scandinavian settlements of Minnesota or the German colonies of Texas", nor "examplesof 'Basque towns' in cities sich as Boise, Reno and San Francisco" (DOUGLASS, 1996, p. 185), the continuity of the process of immigration thanks to the system of chain migration led to the cementation of sufficiently large ethnic subcommunities, numerous enough to make them visible from the outside, to the rest of the local societies they were living in (RAY; BIETER, 2015, p. 78). The process of creation of a distinguishable, socially separate Basque identity from the perspective of their new American neighbors passed through two stages (ALVAREZ-GILA, 2015[b], p. 284). First of all, the very same name of the group had to be known and recognized. After their arrival to the United States, Basque immigrants were somehow "hidden" behind other more widely recognized ethnic and/or national identities: before being Basque, Basques were identified (and identified themselves) either as French or as Spanish. It took Basques some time to create their own, distinct image in the host society, in a process that was no uniform: "the shift from these Spanish or French national identities to the development of a new Basque one happened quicker and sooner with the Basques from Spain, accelerated by the Spanish-American war of 1898" (ALVAREZ-GILA, 2013, p. 9). ${ }^{1}$ Secondly, the identity of the language, culture, settlement patterns and job specialization among both branches of Basque immigrants helped to construct common spaces of relationship and image, whose implementation started by the 1930s (the creation of the first Basque clubs and mutual aid associations) and got reinforced with the establishment of the first national Basque association that encompassed all the previous local Basque ethnic institutions without distinction of origin (CAMUS-ETCHECOPAR, 2007).

\section{Basque Immigration on-screen}

It has been long known that cinema, television, and other more recent means for transmitting and disseminating stories (either fictional or documentary) by the use of moving images have played a central role in the process of construction, spreading, acceptance and consolidation of ethnic stereotypes (KRACAUER, 1949; PERIVOLAROPOULOU, 2007; ALVAREZ-GILA, 2016). As Leerssen (2007, p. 26) recognizes, cinema "is a privileged genre for the dissemination of stereotypes, because it often works on the presupposition of a 'sus- 
pension of disbelief' and some (at least aesthetic) appreciative credit among the audience". Even though there has been some criticism for decades about the limits and usefulness of the concept of "ethnic stereotype", it is still a valuable label to define some of the bidirectional elements of recognition of any ethnic minority group within a wider society, as was the case for Basques and other immigrants in the context of American society during the period of mass migration. Ethnic stereotypes, even though they can be regarded, like Bringham does, as "generalizations that are considered as unjustified by the person who affixes the label" (BRINGHAM, 1971, p. 17), must not be rejected because of their lack of validity for a true description of the collective traits of the group they are ascribed to (TAYLOR; ABOUD, 1973). Stereotypes - and more concretely their resistance to change - (BRINGHAM, 1971, p. 20) condition the way any ethnic group is accepted and are determinant either in helping or in impeding its path towards integration,

As it has been previoulsy noticed, the representation of Basques in American cinema (and in a latter stage, also television) "was deeply conditioned by the historical experience of Basque immigrants in the United States, whose motivations and challenges, and to a greater extent, the peculiarities of their economic integration and social adaptation process, were paramount in their portrayal" (ALVAREZ-GILA, forthcoming, p. 3). This means that, from the eyes of Hollywood, Basques would always be primarily seen as shepherds. Actually, the very first Basque character represented as such in an American film² was no more than an unnamed "Basque Sheepherder". Based upon the homonymous novel by the prolific popular writer Peter B. Kyne, the film presented the typicaly western scenery of Indians, pioneers, cow-boys, gold-seekers, desert landscapes and wild mountains, along with the presence of Lousteau, "a Basque shepherd who couldn't produce the documents entitling him to graze his woollies on the government reserve" (KYNE, 1914, p. 57). The subject matter of both the book and the movie reflected another chapter of the so-called "Sheep and Cattle Wars" that confronted sheepmen and cattlemen over grazing rights all over the West. ${ }^{3}$

The symbiotic identification with sheepherding has thus characterised the most long-standing stereotype of Basque ethnicity by American cinema. As it has been shown in previous articles, the big majority of all the Basque characters depicted in Hollywood films since this very first movie, up to the beginning of the decade of 1980 , were more or less directly linked to the sheep industry (ALVAREZ-GILA, 2015[a], 2015[b], 2016; ALVAREZ-GILA; ARRANZ-OTEGUI, 2014). In fact, this was the only element of the Basque cinematic stereotype present from the beginning. Other elements, such as racial features, linguistic and cultural background and external look (especially clothing) were introduced into the components of the stereotype in succesive stages during the following decades. Several hurdles hindered Basque stereotype in its path toward recognition. First of all, because of their political (in opposition to ethnic) nationality, Basques were first randomly presented with stereotypical ethnic features either of the Spaniards - or, more often, the Spanish or Latin Americans -, or of the French, or even of several degreesof mixture of all of them. Even after the starting point of the creation and emergence of a particular and separate 
ethnic image of the Basque-Americans, it could be still noticed how numerous elements of these other ethnic stereotypes were still applied frequently to them, in a combination of some pieces that clearly belonged to the Basque cultural traits with others that were no more than the persistence of an early, mistaken attribution: language, accent, names and even race of the Basque people will usually refer to the Hispanic/Latin American cultural image when depicted on screen (ALVAREZ-GILA, 2015[a], p. 194-195). Along with that, since the 1940s a new element of visual differentiation was introduced and soon crystallised into the most common way of representing Basques:

The adoption of a specific, ethnically marked clothing, identified
with - or derived from - the traditional, folkloric costume as it was
established in the beginning of the 20 th century and used afterwards
by performers of traditional, folkloric dances and music. This
costume as presented in the movies was always composed in the
case of the men, at least, of the traditional Basque beret (or txapela),
a white shirt, and a red belt (or gerriko), in an suit very closely related
to the costume traditionally used by the participants in the "running
of the bulls" in Pamplona, Navarre. It could also be completed by
the addition of other elements, not so habitual, like a handkerchief
around the neck, a sleeveless jacket, and/or the traditional esparto
shoes or espartinak (ALVAREZ-GILA, 2015[b], p. 299).

The arrival of television as a new contestant in the race for attracting audiences also helped the diffusion and fixation of this visual stereotype, thanks to classical Western television serials like Tales of Wells Fargo (1957-1965), Gunsmoke (1955-1975), Wagon Train (1957-1965), The Big Valley (1965-1969) or Bonanza (1959-1973). With the only exception of the last one, all the rest of these serials had, at least, one episode devoted to developing a story centered on Basque sheepherders. So, we can assume that this way most American cinema and television viewers got used to identifying Basques on the screen by the time Wild is the Wind, the movie we will center upon, was filmed and released.

\section{Ferando/Bene: The 'unusual' Basque of Wild is the Wind}

In 1955 the famous Italian actress Anna Magnani, with a long filmography in her home country, was called to participate in her first American experience by director Daniel Mann. The Rose Tattoo, based on a script by Tennessee Williams, was a huge success: Magnani played an Italian-American widow living in Souther Lousiana, a role for which she won the 1955 Academy Award for Best Actress. This early success opened her the gates of Hollywwod. Soon after the release of The Rose Tattoo, she tried to convince independent producer Hal Wallis to propose Paramount Pictures "the English-language remake of the Italian Furia (1947), based on Giovanni Verga's La Lupa, a lurid melodrama" (DICK, 2015, p. 144). Magnani had expressed her strong interest and commitment with the project from the beginning (VACCARELLA; VACCARELLA, 2005, p. 57). In a letter sent on June 1956 to Hal Wallis himself, she insisted that:

Solo ancora un punto riguardo a Furia. Ė un vero peccato, e sono veramente molto sorpresa, che nessun autore abbia trovato il modo 
di farne un grande film. [...] Comunque quello che dovrebbe essere completamente evidenziato è quella morbosa passione, quasi non salutare, ma tuttavia così umana, di una donna matura per un giovane uomo. L'intera relazione dovrebbe essere inserita in un ambiente deserto, privo di ogni segno di vita come i tuoi magnifici ed immensi allevamenti di cavalli nelle fattorie (VACCARELLA; VACCARELLA, 2005, p. 88-89). ${ }^{4}$

In fact, the plot of the film, originally located in a horse farm in Northern Itally, would be "naturally" adapted, in the American enviroment, to the solitude of the ranches in desertic Nevada, changing horses for sheep. But this was not the only change: while the bulk of characters continued to be Italian (or Italian-American) in the remake, one of them, and only him, happened not to be Italian, but Basque:

\begin{abstract}
Wild is the Wind [...] uses the subject of extra-marital affairs, played out by two Europeans, an Italian woman and a Basque man, living in America. Wild is the Wind might also be called another Lost in Translation, since communication seems to be impossible between the Italian woman and her American environment, the American family she has married into. There are stereotyped images of the different nationalities represented involved: the outgoing, spontaneous, sentimental and passionate Italian woman; a silent, introverted, distant and hard-working Basque man, who, nonetheless seduces a married woman. The American husband (played by Anthony Quinn) has imported everything from Europe: the Basque man whom he employs and whom he considers almost as an adopted son, his Italian first and second wives (remarrying, as a widower, the sister of his dead first wife) (NAVARRO MARTÍNEZ, 2009, p. 16-17).
\end{abstract}

Why and how was a Basque character introduced into the cast of the film? It was not the outcome of an early decision but, as we will describe here, it took a lenghty process for the filmakers to arrive to the conclusion that Ferando or Bene (his name and nickname in the movie) could not be anything else but a Basque.

Wild is the Wind is supposed to be one of the few Hollywood approaches to the neorealism movement of the post-World War II Italian cinema. As Brunstein (1959, p. 23) states, we must understand this film within the context in which the film industry in Hollywood "is losing its sharpness of focus and assuming the murkier tones hitherto associated with European realism. [...] Film-makers are beginning to assume attitudes toward their products which, twenty years ago, they would have considered visionary and impractical". Now it is not "artificial merchandise" but "the complex stuff of life" which attracts the attention of filmkakers. ${ }^{5}$ Originally John Sturges was slated for director, but after he became ill, the position was offered to George Cukor with the instant approval of Magnani (LEVY, 2006). Anyhow, according to Nochimson (2014, p. 76) this film can be considered an entirely Cukorian creation, not only because it is a return to the theme of the outsider, that "some critics have tried to trace in his filmography", but also because Cukor "never wrote his own scripts and almost always worked with scripts adapted from novels and plays", as this is the case. 
The film, whose primary provisional title throught production was A Woman's Obsession, was supposed to start by the beginning of April. Magnani had thus arrived from Italy in February 1957 (VACCARELLA; VACCARELLA, 2005, p. 118); but the problems with the replacement of the director caused a small delay. One of the most relevant elements of the film is based on the use of scenery and depiction of air (FERGUSON, 2011). Because of this, most of the filming had to be done on natural locations. The headquarters of the staff were therefore located in El Rancho Motel of Carson City, Nevada, and the filming area ranged from Reno airport in the north to Genoa and Minden in the south ${ }^{6}$ - the latter one being the place where the fictional ranch was located. ${ }^{7}$ On April 28 the technical staff arrived by road, while the main actors travelled by air from Los Angeles to the nearby Reno airport. Filming in Nevada with the main actors lasted until May 19, when the first unit returned to Hollywood to film the interiors. ${ }^{8}$ The shooting of the movie ended by June 21st. On 11th September, 1957, Anna Magnani was back in Italy, where she wrote Hal Wallis about the editing of the film, that was by then finished: "Al telefono non ti ho domandato se il montaggio di 'Wild is the Wind' era terminato e se era come tu lo desideravi. Ci hai rimesso le scene d'amore che piacevano sia a te che a me? Le piu belle e audaci? Compresa quella famosa dopo la nascita degli agnelli, il bacio a la fine?" (VACCARELLA; VACCARELLA, 2005, p. 119). ${ }^{9}$ Actually, this scene about the birth of the lambs that Anna quotes is closely related to the process of transformation of Ferando/Bene from an Italian (as he was in the earliest versions of the script) into the Basque he was finally turned into.

The original documentation on the shooting process of the movie, as it is conserved in the library of the Academy of Motion Pictures (George Cukor Collection), offers us a privileged window to look into the evolutionary process of creation of the character of Ferando/ Bene. In the early versions of the script, everything there is about Italy, Italians and the difficulty to adapt to their new American cultural environment of two of the main protagonists of the love triangle that sets the main theme of the plot: Gioia, the wife, played by Magnani herself; and Ferando/Bene, played by Anthony (Tony) Franciosa. In fact, we cannot keep away from the supposition that his Italo-American background was somehow behind his selection to play this character. To a certain extent, some of the features that defined the character of Gioia on screen were shared by the personal life of Anna Magnani. One of the problems she became fully aware of during the ellaboration of this film, and all along her American career, was her lack of mastery over English. "I am rewriting in a more detailed manner all sequences from the beginning to the end of the picture", she complained during the reviewing of the script, "because, due to my insufficient mastery of the English language, I obviously was unable to explain myself well, and on his side the author has obviously not understood what I meant to say". ${ }^{10}$ The confusion and loneliness derived from her difficulties and useless struggles to learn a new language is what, almost from the beginning, would create the link between the two characters and turn them into lovers: "She feels lost", analysed Magnani in her notes and observations about the character of Gioia. "Like a foreigner in a country that is not her own, forced to live with a man she does not know very 
well, and where everybody else speaks a language which she does not understand". ${ }^{11}$ Only Bene, that had passed through the same experience when he was brought to the United States as an orphan by Gino, seems to understand her during the family meeting at her first dinner in America: "Everyone is talking at the same time, creating a lot of confusion. All except Bene. He has been watching Bella and he understands how lost she feels. Bella, in fact, is confused. She does feel lost and surprised and a little frightened". ${ }^{12}$

Bene being a foreinger was therefore a capital element to fully understand the main line of the argument. Regarded as a son by Gino, it soon becomes clear that both Bene and Gioia share many things in common. The experience of migration (although of clear Italian heritage, it is never precisely stated in the film whether Gino is American born or not), travelling under traumatic conditions, ${ }^{13}$ the necessity to learn and adapt to a new language, and the initial loneliness are elements that bind them together. ${ }^{14}$ That is why both the director (Cukor) and the promoter of the film and co-star (Magnani) highlighted the importance of stressing this feature of the character of Ferando/Bene once and once again in their remarks on the following versions of the script. For instance, on 7th April, 1957, Magnani wrote to Cukor that a better explanation of this aspect during the opening sequences would "clarify the entire story". ${ }^{15}$

Nonetheless, during the whole process of revision of the script until the almost last version of it, Ferando/Bene still continues to be regarded as an Italian. A few days before the actual shooting would start, on April 17, George Cukor wrote a memorandum to Paul Nathan, associate producer of the film, in which he reminded him of the arrangement to visit "some Italian families with: Tambi Larsen, Arthur Krams, Toni Franciosa, Man to take stills" next Saturday. ${ }^{16}$ Undoubtedly this can only be interpreted as a way to strengthen and reinforce the accuracy and realism of the representation of the "Italianness" of his character and the whole film: Larsen was the art director and Krams the art designer. On the same day another protagonist of the film, the actress Dolores Hart - who would be in charge of playing Angie, the nineteen-year-old daughter of Gino - was scheduled to rehears her scenes, "see film on Verde at Metro- and the fat Italian actress from New York" in order to improve her abilities to impersonate an Italian-American, after the producers had had a bitter quarrel with Magnani who did not consider Hart the most adequate actress for this role because "she was not Italian" (HART, 2013, p. 48). ${ }^{17}$ All the exterior shots were thus filmed while Bene was still considered to be as Italian as his counterparts.

\section{Learning what a Basque is}

Nevada is the land of sheep rather than of horses, so it was decided, since this state was selected to be the setting where the original play was to be adapted in this remake, that the ranch owned by Gino - in which the plot of the film would be developed - had to be one of sheepherding. As soon as in December 12, 1956, Hal Wallis had received a letter from Richard A. Blaydon, production manager, in which he was informed of the contacts he 
had made with several sheepherding ranch owners in California, Idaho, Wyoming, Arizona and Nevada that had initially agreed to serve as the filming location for the exterior takes, stating also the best suitable dates for shooting. ${ }^{18}$ By then Arnold Schulman, in charge of writing the screenplay, had been provided by the library service of Paramount Pictures with first and second hand literature and documentation to help him in the process of recreation of the ambience and background of the film. Apart from several "films on sheep" that Cukor himself watched in order to get involved in the visual atmosphere of sheepherding as closely as possible before the actual shooting, ${ }^{19}$ the list included some books on the economic value of sheepherding and wool production in the United States, but most of the items were articles published in popular journals such as National Geographic or Life. Among others, Schulman is assumed to have used the report "Grass Makes Wyoming Fat" by Frederick Simpich, ${ }^{20}$ from which we can trace the origin of some of the scenes introduced into the screenplay, related to the use of sheepdogs to count sheep:

\footnotetext{
You're waist-deep in sheep out there. Their voice dominates other sounds.

Sheepherders' white-topped wagons dot the hills, and thousands of trained dogs help herd more than three million sheep. These dogs scamper over the bacs of flocks, using each animal as a steppingstone. Some large ranches work from 100 to 175 dogs. Often the herders also use a "tin dog", a string of empty tin cans which they rattle to keep the sheep moving.

To count lambs, when they are "docked", or have their tails cut off, men put the tails in piles of ten, then add up the piles. ${ }^{21}$
}

Nevertheless, Simpich does not mention any Basque among those that came to the West "to start sheep and cattle ranches. [...] Some of the British and Danes came as Mormon converts. Here, too, are Russians, Swedes, Germans, Italians, Mexicans and Orientals". Where were the Basques, then? One of the last articles from the list will give us the answer. On 12th May 1945, Life magazine had published a 6 page article, full of photographs, whose title was clear enough: "Basque Shepherd. U.S. Immigrant Works amid the Alien Lambs". The protagonist is a young Basque shepherd, recently arrived from France, called Bertrand Borda. 22 The opening text of the article underlines the close connection between Basques and sheepherding in the American West, an argument that is constantly repeated and justified all along the text:

In the sage-covered hills of the Rockies, along with the familiar and welcome bleating of newborn lambs, ranchers this spring are hearing less familiar but even more welcome sounds - the soothing words of Basque shepherds talking to their sheep. Their words are outlandish - Ene ardi maiteak means good sheep, ixan onak means calm down - and their neat berets look strange in the 10-gallonhat country of the American West. But, in the current shortage of American herders, the foreign ways of 450 Basques who have been imported recently work wonders in the U.S. grazing lands (MYDANS, 1945, p. 125).

From a close analysis of the content of these articles and documents, it seems clear that Arnold Schulman actually introduced some of the information he found there into 
the script. This is the case, for instance, of the previoulsy quoted scene of the birth of the lambs. This scene was assumed to be a pivotal moment in the development of the plot, the introduction to the first love scene between Gioia [Bella in the first versions] and Bene, a "magnificient episode [...] followed by Bella's fear when she takes haven in the arms of Bene. Because this is the moment during which Bella and Bene feel their first real emotion":23

[...] after an ardurous and tiring day of lambing with the sheep, the contact with this physical animal life, of maternity, of sex, roses in them both an instinctive sensuality, a human warmth, a desire within themselves. ${ }^{24}$

The earlier versions of the script said almost nothing about how this scene would be. This abruptly changed in the last and definitive version of the script, sent by Arnold Schulman to Hal Wallis on 26th April 1957. In the 1945 article in Life, the author had thoroughly described what Basque shepherds did when a newborn lamb lost her mother during delivery. "A ewe will nurse only her own lamb or one that she thinks is hers", wrote Mydans, "so Bertrand and his fellow sheepherders use an ingenious bit of deception to bring together orphan lambs and foster mothers":

\begin{abstract}
When a lamb loses its mother, shepherds must get a new mother to feed it. They find a ewe whose lamb has died - she usually stands near the body - and cover the motherless lamb with the skin of the dead one. Because the ewe recognizes her lamb by its smell, she is deceived by the hide into thinking the stranger is her own offspring, and she often allows the lam in lamb's clothing to nurse. After a day of this deception the lamb is fully accepted by its new mother, and the old hide is no longer needed (MYDANS, 1945, p. 127).
\end{abstract}

The whole scene was therefore rewritten, changing the generic emotion because of "the maternity" into a more specific situation in which Ferando/Bene, as Bertrand Borda did to Mydans several years earlier, would explain to Gioia what he was about to do to save the life of an orphan lamb in the film and why.

Nevertheles, it was clear by then that it would make a lot of sense to introduce Basque characters into the film in order to reflect with some degree of accuracy the reality of the sheep industry in Nevada. On the other hand, it was also clearly impossible to change the nationality of two of the main protagonists of the film - Anna Magnani was understood to be too Italian to become credible in a role other than someone of her own ethnicity -, but not the third one, that could be quickly transformed to having Basque origins: this change would not affect the main lines of a story. Therefore in the same definitive version of the script, some elements were introduce to explain that (and justify why) Ferando/Bene was a Basque.

From this point of view, Wild is the Wind presents a high level of discrepancy with what was, at thate moment, the consolidated way of representing Basques on screen. As it has been said before, during the 1950s a visual stereotype of the Basque immigrant had somehow been established in the cinematic and television production in the United States: Basques were always represented with Spanish racial and cultural features (speakers 
of Spanish, small, dark-skinned; in other words, close to the stereotype of the Mexican) and a set of folkloric costumes to be quickly recognised by the audience (ALVAREZ-GILA, 2015[a], 2015[b]). However, this resource was not used in this film. Ferando/Bene never wore anything other than average Western American clothes during the whole movie; and even though the actor that played this role, Franciosa, had some kind of an ethnic touch because of his Italian origins, he was indeed very far away from the stereotypical image of the Mexican/Folklorik Basque that was quite usual at that moment in Hollywood. We cannot anyway determine if this was a deliberate decision, or a mere consequence of the lack of time and the need to finish the movie on time without unnecesary (and costly) changes and further delays.

Nevertheless, some other elements of the stereotypical image of the Basque immigrant in the United States, as it had been constructed for a long period, permeating into popular literature first (AROSTEGUI, 2014) and from here into cinema later, were introduced into the script. It is interesting to highlight that the focus on the Basqueness of Ferando/ Bene was restricted to lengthy explanations in dialogues that always took place in the interiors - being therefore those shoots that were filmed at the end, in the Paramount studios at Hollywood, once the staff and actors returned back from Nevada.

In the film, we are first told about the nationality of Bene when the protagonists are going to the ranch after receiving Gioia at the airport:

[Take 34] GINO. - ... so I take care the business end, and Bene's like my... Bene I call him Bene. His real name is - (He laughs, looks to Bene for help) I can't even say it.

BENE. - Ferando.

GINO. - You ever seen a crazy name? He's a Basque. You know a Basque? In Spain. In the whole world, the best sheepherders for hundreds of - (suddenly pointing something out) Look! You see where the trees are? [...] Anyhow, what I wanted to say. My papa's name was Bene, so I always said when I get me a son...25

Needless to say, Ferando is by no means a Basque name at all, even though the practice of putting Spanish-like names to Basque characters was commonplace at that moment in American film production. But what is more significant is the introduction of the topic of sheepherding as being part of the core identity of Basques. The idea of Basques being "the best sheepherders" in the world was not an invention of Schulman, but the common explanation that their fellow Americans had developed to explain the massive Basque participation in this field in the West (ALVAREZ-GILA; ARRANZ-OTEGUI, 2014). The fictional Gino himself will come back to the topic a bit later, trying to explain why Bene had been working with him since he was a little child:

[Take 56] GINO

She speaks pretty good English, huh? A few words. But very clear. Wait. She'll pick up like that. Remember Bene you came over? He couldn't speak two words.

(To Gioia) I brought him over here, Bene. He's a little boy. Bambino. Bene. Eight, nine years old. I never seen him even. I wrote a letter the 
church in Spain. I told them send me a little boy's going to live with me. A Basque I wanted. Somebody's got it in his blood the sheep. Huh, Bene? Worked out pretty good, my surprise package. ${ }^{26}$

"The Basques, they've got a sheep in the blood". Anthony Quinn, as it was usual in this film, changed the phrasing of his dialogue in the script slightly, providing the audience a more descriptive, almost metaphoric explanation of the special relationship between Basques and sheep. References to the mastery of Basques when referring to sheepherding will continue to appear throughout the film. "Only a Basque, in this country, can train a dog like that", ${ }^{27}$ gladly explained Gino to his wife while Bene was giving orders to the sheepdogs to herd a big flock of sheep into the stable. If not the visual stereotype, at least all the rest of the elements that composed it were therefore admitted and introduced into the film.

\section{Conclusion}

Who where the Basques? Wild is the Wind does not get into the task of trying to explain the question about their origin and cultural background, nor gets involved in an also stereotypical attempt to elucidate about the exoticism of Basque language and ethnicity in the European context. Only general references to the geographical context of the Basque Country being in Spain appear. It was neither the intention of the producers, director and scriptwriters of this movie to make a film about the Basques, nor their interest to deliberately put a bit of exotic ethnicity in the film from its inception. Only after a research aimed at accurately contextualising and giving veracity to the depiction of events and social and economic background to the plot of a film that was intended to be "realist", did Basques appear in the film. As unexpected guests, the film had to be rewritten in order to reflect what was understood to be the real situation of shepherding in Nevada, with a virtual monopoly of Basques in this economic activity. The last-moment transformation of Ferando/ Bene into a Basque had therefore to be explained by the use of the stereotipycal discourse on Basque immigration that was commonplace, especially in the Western American states most Basque immigrants had settled down: a discourse that the primary audience of the film shared and accepted. Stereotypes in cinema are usually double-faced: they are not only spread by the force of the moving images, but they also are a necessity for filmmakers in order to achieve the goal of reaching the acceptance of audiences more easily.

\section{References}

ALVAREZ-GILA, O. Changes on Perception of Ethnic Identity after the End of Mass Migration. The Basques in the United States. Amnis, special issue "Transnational Mobility and Exchanges between Europe and America", Brest, n. 12, 2013.

ALVAREZ-GILA, O. Etnicidad, geografía y folclore en la construcción del estereotipo del inmigrante vasco en el cine norteamericano. In: GONZÁLEZ MARTÍNEZ, E.; GONZÁLEZ 
LEANDRI, R. (eds.). Migraciones Transatlánticas: desplazamientos, etnicidad y políticas. Madrid: Catarata, p. 175-197, 2015[a].

ALVAREZ-GILA, O. Western Gypsies or Eastern Mexicans? Exoticism and Ignorance in the Construction of the Image of Basque Immigrants in American Cinema, 1913-1980. Studia Migracyjne - Przegląd Polonijny, Krakow, v. 51, n. 4, p. 283-301, 2015[b].

ALVAREZ-GILA, O. Los estereotipos del emigrado vasco en el cine americano, de los orígenes a nuestros días. In: paper presented at the International Conference Les Arts et la Diaspora Basque (XIXe-XXe siècles), Bayonne (France), 25-26 Febr. 2016.

ALVAREZ-GILA, O. Undesirable Guests: Basque Americans and Domestic Terrorism on Screen, 1985-2015. Archivio Storico dell'Emigrazione Italiana, Viterbo (Italy), forthcoming.

ALVAREZ-GILA, O.; ARRANZ-OTAEGUI, I. La imagen del inmigrante vasco en el cine: ¿reflejo, construcción o refuerzo de los estereotipos sociales?. Sesión no numerada. Revista de letras y ficción audiovisual, Madrid, n. 4, p. 68-96, 2014.

AROSTEGUI, E. The Construction of Basque-American Identity: Stereotypes and Imagery in Western Literature. In: paper presented at the American Ethnicity and East European Immigration Conference, Cracow (Poland), June 15-18, 2014.

BIETER, J. P.; BIETER, M. An Enduring Legacy. The Story of Basques in Idaho. Reno NV: Center for Basque Studies, 2003.

BRINGHAM, J.C. Ethnic Stereotypes. Psychological Bulletin, Champaing IL, v. 76, n. 1, p. 15-38, 1971.

BRUSTEIN, R. The New Hollywood: Myth and Anti-Myth. Film Quarterly, Oakland CA, v. 12, n. 3, p. 23-31, 1959.

CAMUS-ETCHECOPAR, A. The North American Basque Organizations (NABO). Incorporated. Ipar Amerikako Euskal Elkarteak, 1973-2007. Vitoria-Gasteiz: Basque Government Publishing Service, 2007.

CHASE, D. Anna Magnani: Miracle worker. Film Comment, New York, v. 29, n. 6, p. 42, 1993.

DICK, B.F. Hal Wallis. Producer to the Stars. Lexington KY: University Press of Kentucky, 2015.

DOUGLASS, W. A. The Vanishing Basque Sheepherder. The American West, v. 17, n. 4, p. 
30-31 and 59-61, 1980.

DOUGLASS, W. A. Basque-American Identity. Past Perspectives and Future Prospects. In: TCHUDI, S. (dir.). Change in the American West. Exploring the Human Dimension. Reno, NV: University of Nevada Press, 1996. p. 183-199.

DOUGLASS, W. A. Factors in the Formation of the New World Basque Emigrant Diaspora. In: Global Vasconia. Reno, NV: Center for Basque Studies, 2006. p. 20-32.

DOUGLASS, W. A. Basque Immigration in the United States. Boga. Basque Studies Consortium Journal, v. 1, n. 1, art. 5, 2013.

DOUGLASS, W.A.; BILBAO, J. Amerikanuak. Basques in the New World. Reno, NV: University of Nevada Press, 1975.

FERGUSON, K. L. Panting in the Dark. The Ambivalence of Air in Cinema. Camera Obscura, XXXX, v. 26, n. 2, p. 33-63, 2011.

HART, D. The Ear of the Heart. An Actress' Journey from Hollywood to Holy Vows. San Francisco: Ignatius Press, 2013.

KRACAUER, S. National Types as Hollywood Presents Them. Public Opinion Quarterly, Oxford, v. 13, n. 1, p. 53-72, 1949.

KYNE, P.B. The Parson of Panamint and Other Stories. New York: Grosset \& Dunlap Publishers, 1914.

LEERSSEN, J. Imagology. History and Method. In: BELLER, M.; LEERSSEN, J. (eds.). Imagology: The Cultural Construction and Literary Representation of National Characters. A Critical Survey. Amsterdam: Rodopi, p. 17-32, 2007.

LEVY, E. Wild is the Wind: How George Cukor Tamed Anna Magnani. Emanuel Levy Cinema 24, 7, Jul. 11, 2006.

MYDANS, C. Basque Shepherd U.S. Immigrant Works amid the Alien Lambs. Life, May 12, p. 124-129, 1945.

NAVARRO MARTÍNEZ, E. Images of Europe in American Films, 1921-1962. Amsterdam: Opleiding Europese Studies - Universiteit van Amsterdam, 2009.

NOCHIMSON, M. P. George Cukor. In: LEONARD, S.; TASKER, Y. (eds.). Fifty Hollywood Di- 
rectors. Oxford: Routledge, p. 76-84, 2014

PERIVOLAROPOULOU, N. Les stéreotypes nationaux dans le cinéma hollywoodien vus par S. Kracauer. Bulletin Trimestrel de la Fondation Auschwitz, Brussels, n. 94, p. 81-90, 2007.

RAY, N. M.; BIETER, J. P. 'It Broadens Your View of Being Basque'. Identity through History, Branding and Cultural Policy. International Journal of Cultural Policy, Warwick, v. 21, n. 3, p. 241-257, 2015.

TAYLOR, D. M; ABOUD, F. E. Ethnic Stereotypes. Is the Conceot Necessary? Canadian Psychologist / Psychologie Canadienne, Montréal, v. 14, n. 4, p. 330-338, 1973.

TOTORICAGUENA, G. Mendiko Euskaldun Cluba: Minden and Gardneville. Nevada: Euskonews \& Media, \#208, 2003. Available at: <http://www.euskonews.com/0208zbk/kosmo20802.html>.

TOTORICAGUENA, G. Basque Diaspora. Migration and Transnational Identity. Reno, NV: Center for Basque Studies, 2005

VACCARELLA, C.; VACCARELLA, L. Anna Magnani. La mia corrispondenza americana. Roma: Edizioni Interculturali, 2005.

\section{Notas}

1 Moreover, this process "was helped by the fact that very few of them were proficient on the Spanish language so it became easier for them to get away from the public image of average Spaniards".

2 The Land Just Over Yonder. Dir. Julius Frankenburg, Dudley Motion Company, 1916.

3 The starting point of the narration is the killing of the Basque shepherd. After arguing with the protagonist, "the Basque decided it would be far easier to remove Billy Boy than the sheep, so from ambush he potted Billy Bo through the right shoulder at three hundred yards. The bullet lifted the ranger out of his saddle, and when he struck the grount he had the good sense to lie perfectly still. The Basque watched for five minutes, conclude he had done a thorough job and neglected to investigate". That very night Billy Boy returned to the sheep camp and killed the Basque (KYNE, 1914, p. 57-58).

4 The original letter must surely be written in English, although it was translated into Italian by the authors of this compilation. A re-translation into English could be like follows: "Finally a last remark with regard to Furia. It is a real sin, and I am really very surprised to know that nobody had found the way of turning it into a big movie. [...] Nonetheless, the most remarkable thing [in the film] would be the morbid passion, almost insane but all the same totally human, of a mature woman for a young man. The whole relationship should be placed into a desert environment, without any sign of life, like your magnificent, immense horse ranchs". I wish to thank my colleage Consolación Fernández Mellén, from the University of the Basque Country, her help in understanding and translating the text in Italian.

5 "Anna Magnani once said that Wild is the Wind and The Fugitive Kind, her two post-Tattoo Hollywood films, 'suffer a bit from mannerism'" (CHASE, 1993). Margaret Herrick Library, Academy of Motion Pictures

6 Margaret Herrick Library, Academy of Motion Pictures: Beverly Hills, California (from now on, MHL-AMP). Special Collections (from now on SC). "Paramount Pictures Production Records" 237.f-5: Wild is the Wind - script supervisor's notes 1957. Shooting scenes were among others, the airport of Reno (initial sequence) and a sheep 
ranch close to Minden, and the road linking Carson City with Minden. The only sequence filmed outside Nevada was shot in the outskirts of Mountain Meadow near Woodford, California.

7 The Carson river valley, in which both Genoa and Minden are located, is the center of an active, long-standing Basque-American community whose roots date back to the end of the 19th century and whose history has been directly linked to sheepherding activities. Several Basque clubs and restaurants still maintain Basque presence in the area today (TOTORICAGUENA, 2003).

8 MHL-AMP. SC. "Paramount Pictures Production Records" 237.f-4: Wild is the Wind - movements 1957. Location movement orders.

9 "I haven't asked you by telephone if the editing of Wild is the Wind has finished and, if affirmative, it it has been done as you wished. Have you reintroduced the love scenes we liked? The most beautiful and audacious ones? Including that famous one after the birth of the lambs, the kiss at the end?" translated by Consolación Fernández Mellén.

10 MHL-AMP. SC. "George Cukor Collection" 27.f-287: Wild is the Wind. "Synopsis by Anna Magnani", April 7, 1957 [21 pages], p. 1. This document comprises "a resume of all picture sequences" that "for a better understanding, Miss Ana Magnani has rewritten [...] from the beginning to the end, as they have been discussed and agreed upon between the author and herself".

11 MHL-AMP. SC. "George Cukor Collection" 27.f-287: Wild is the Wind. "Notes and observations of Anna Magnani", April 7, 1957, p. 2.

12 "Bella" is the first name given to the character played by Magnani, that would latter change into Gioia. Because of the stress put by Magnani in this element, in a second version of the script there is an importan addition when describing the very same scene of the first dinner in America of Gioia: "ARRIVAL AT THE HOUSE: - (NIGHT) The family meets BELLA. The confusion at the dinner table. BELLA goes outside. BENE follows her. BELLA and BENE have a scene, in which BENE undestands her problems. They go back to the house" (MHL-AMP. SC. "George Cukor Collection" 27.f-287: Wild is the Wind. "Step Continuity", April 15, 1957, 3+5 pages).

13 As it has been said before, Bene arrived to America after bein orphaned and adopted by Gino. Gioia, for her part, was the sister of the previous wife of Gino, who went to Italy to marry her after widowing.

14 MHL-AMP. SC. "George Cukor Collection" 27.f-290: Wild is the Wind. "Handwritten notes by George Cukor regarding script", Undated. George Cukor affirmed: "I like the explanation of Bene's name - named after Gino's father. His background (as in black script - we found out about him through Bella's eyes-)".

15 MHL-AMP. SC. "George Cukor Collection" 27.f-287: Wild is the Wind. "Synopsis by Anna Magnani", April 7, 1957 [21 pages], p. 2.

16 MHL-AMP. SC. "George Cukor Collection" 27.f-293: Wild is the Wind. "Memo to Paul Nathan", April 17, 1957.

17 Dolores Hart herself remembered her first encounter with Magnani in her memories as follows: "Before I had a chance to kneel at her feet, she glared at me and shook her hear, 'No, no, no'. The corners of her mouth drooped while she loiked me up and down over the dark glasses. She stared at my eyes and threw up her hands. 'No!' [...] Her English was not good, so she yelled in Italian, with Pamela translating as fast as she could. I could catch only bits and pieces of the tirade - words such as inexperienced and amateur. I was devastated. [...] 'She's not Italian', Anna shouted, and then I heard Mr. Cukor say, 'But she is Italian. She could do the entire scene in Italian!' [...] 'The eyes, they're blue!' she barked".

18 MHL-AMP. SC. "George Cukor Collection" 27.f-293: Wild is the Wind. "Inter Office Communications: Films on Sheep", April 22, 1957. Leonar Hammond to George Cukor. The films included in the list were Arizona Sheep Dog (2 reels) and Border Collies (a Disney film), both available at the office of Hal Wallis Productions. By April 24 they had also "been promised a film from the University of California which is the one Arnold Schulman thought would be of interest. This is called, 'And Now Miguel'". The document finishes with some handwriting remarks on the films by Cukor himself.

19 MHL-AMP. SC. "George Cukor Collection" 27.f-293: Wild is the Wind. "S.F. 83060 - Furia".

20 SIMPICH, Frederick. National Geographic, LXXXVIII, 2, p. 153-188.

21 SIMPICH, Frederick. National Geographic, LXXXVIII, 2, p. 160.

22 A short biographical note on Bertrand Borda, by Koldo San Sebastián, in the blog "Amerikanuak. Historias de la emigración vasca en América". Available at: <http://amerikanuak.blogspot.com.es/2013/01/bertrand-borda-unpastor-vasco-en-life.html>. Entry of 19 Jan. 2013.

23 MHL-AMP. SC. "George Cukor Collection" 27.f-287: Wild is the Wind. "Synopsis by Anna Magnani", April 7, 1957 [21 pages], p. 3.

24 MHL-AMP. SC. "George Cukor Collection" 27.f-287: Wild is the Wind. "Notes and observations of Anna Magnani", 
April 7, 1957, p. 10A

25 MHL-AMP. Core Collections. "Scripts collection" Wild is the Wind (1957): Revised final white script. Arnold Schulman, April 23, 1957. Wallis - Paramount Hazen P10215. The phrasing of this final version of the script does not correspond verbatim with the actual phrasing of the film: there are some minor changes, specially in the part played by Anthony Quinn (Gino), but the overall content and meaning of the dialogue does not change.

26 MHL-AMP. Core Collections. "Scripts collection" Wild is the Wind (1957): Revised final white script. Arnold Schulman, April 23, 1957. Wallis - Paramount Hazen P10215. Once again, Anthony Quinn did not respect the actual phrasing of the script, but the changes do no affect the content of the discourse.

27 MHL-AMP. Core Collections. "Scripts collection" Wild is the Wind (1957): Revised final white script. Arnold Schulman, April 23, 1957. Wallis - Paramount Hazen P10215. Take 76.

Oscar ALVAREZ-GILA. Professor of History of America - Department of Medieval, Early Modern and American History - Faculty of Letters. Unibertsitateko pasealekua, 5; E-01006 Vitoria-Gasteiz, Basque Country, Spain. This article has been produce within the framework of the permanent research group of the Basque system: "The Basque Country, Europe and America: Inter-Atlantic Links and Relationships".

Received on 06/10/2016

Approved on 03/11/2016 